\title{
Global Ethics and Nanotechnology: A Comparison of the Nanoethics Environments of the EU and China
}

\author{
Sally Dalton-Brown
}

Received: 28 February 2012 / Accepted: 17 June 2012 / Published online: 14 July 2012

(C) Springer Science+Business Media B.V. 2012

\begin{abstract}
The following article offers a brief overview of current nanotechnology policy, regulation and ethics in Europe and The People's Republic of China with the intent of noting (dis)similarities in approach, before focusing on the involvement of the public in science and technology policy (i.e. participatory Technology Assessment). The conclusions of this article are, that (a) in terms of nanosafety as expressed through policy and regulation, China PR and the EU have similar approaches towards, and concerns about, nanotoxicity - the official debate on benefits and risks is not markedly different in the two regions; (b) that there is a similar economic drive behind both regions' approach to nanodevelopment, the difference being the degree of public concern admitted; and (c) participation in decision-making is fundamentally different in the two regions. Thus in China PR, the focus is on the responsibility of the scientist; in the EU, it is about government accountability to the public. The formulation of a Code of Conduct for scientists in both regions (China PR's predicted for 2012) reveals both similarity and difference in approach to nanotechnology development. This
\end{abstract}

S. Dalton-Brown $(\bowtie)$

University of Central Lancashire (UCLan),

Preston, UK

e-mail: sdaltonb@trinity.unimelb.edu.au may change, since individual responsibility alone cannot guide S\&T development, and as public participation is increasingly seen globally as integral to governmental decision-making.

Keywords Nanotechnology $\cdot$ China $\cdot$ EU $\cdot$ Regulation · Policy · Nanoethics · Global ethics · Participatory technology assessment

Ought bioethics in East Asia to use the same approaches (assumptions, principles, theories, styles, methods, concepts) as bioethics developed in the West, or ought it to reflect a specifically East Asian approach to the subject? ([18]: 310)

Ethics and socio-ethical analysis have increasingly become an integral part of the assessment of any new technology and its applications [7]. Certain European countries have instigated national programs dedicated to ethics in science and technology (S\&T) (e.g. The Netherlands) or have established institutes to conduct research into the ethical implications of new technologies (e.g. national genomics centres in the UK and The Netherlands). In China PR, ethical, legal and social implications (ELSI) analysis is becoming a more prominent issue when evaluating new $\mathrm{S} \& \mathrm{~T}$ 
developments., but is not yet as well established as in Europe.

A growing trend since the 1980s in terms of S\&T evaluation in the EU has been that of pTA, or participatory Technology Assessment, a drive towards incorporating social concerns into technology assessment through public dialogue. Such a trend has developed under pressure of increasing public scepticism about scientific research and development ([22]: 386). The outcome of such scepticism has been a demand for more informed public debate, and greater public involvement both in how new technologies should be regulated and funded ([14]: 211), and how they should be applied to everyday life. Policymakers anxious not to repeat the mistakes associated with the introduction of biotechnology initiatives such as genetically modified (GM) foods, namely, that 'legislation came too late and with too little public engagement and ethical reflection', began to call for the inclusion of ethical and societal impacts of potentially transformative new technologies at an early stage in policymaking $[21,26]$.

Public dissatisfaction in The People's Republic of China (China PR) after various food safety scandals relating to milk and to gutter oil suggests scepticism about regulation is not only an EU issue. ${ }^{1}$ A China Daily 2010 survey concluded that more than $85 \%$ of respondents were worried about the potential health hazards of GM food. ${ }^{2} \mathrm{Hu} \&$ Chen's earlier survey of Beijing consumers found that consumers' purchase intentions of GM vegetable oil were low, indicating a considerable skepticism toward GM products' [24]. After the granting of biosafety licenses to two rice strains, 120 Chinese academics signed a public petition in March 2010 asking the Ministry of Agriculture to withdraw the certificates [27].

China PR has an established survey process on S\&T public perceptions, but such a process has tended to be quite general, with a lack of surveys on specific issues and more importantly, a dearth

\footnotetext{
${ }^{1}$ The 2008 scandal, when milk from the Sanlu corporation was found to be contaminated by melamine, was China's second major baby-milk scandal. The death toll from the Sanlu contamination varies, according to whom one reads, from 3 to 11 , but up to 300000 children were allegedly reported as affected. The gutter oil scandal erupted in September 2011 after reports of companies recycling oil from drains behind restaurants.

${ }^{2}$ China Daily 3 April, 2010. Retrieved January 7, 2012, from http://www.chinadaily.com.cn/china/2010-03/04/content_ 9534076.htm
}

of implementation processes for using such surveys in policy debates.

Can China PR catch up to Europe in this area? Europe is increasingly co-operating and competing with both China and India, which are also keen to develop their S\&T sectors. Such new interdependences between global actors require, arguably, new global approaches to S\& T policy, or at least, recognition of differing local approaches to what is perhaps a global science, The complex question of whether there can ever be a global approach that does not run the risk of neo-colonialism [3, 49], or an imposition of 'colonial' values on the East aside [19], one can note general similarities in Eastern and Western approaches to the dangers of nanotechnology. The major differences are in the processes by which public concerns are mediated in Europe and China PR.

\section{China PR: Nanohistory, Nanoregulation, Nanopolicy and Nanoethics}

Of the Asian countries, Japan and China are leading the way in nanotechnology. The national program in China PR dates from the establishment of the National Steering Committee for Nanoscience and Nanotechnology (NSCNN) in 2000 to coordinate nationwide efforts on nanotechnology R\&D. The committee is composed of 21 scientists from universities, institutes and industry and 7 administrators from government agencies.

Research goes back 13 years before that, however, to the 1987 National High Technology Plan (or '863 Plan'), that supported ultrafine particles research. In 1990, the State Science and Technology Commission [the predecessor of the current Ministry of Science and Technology (MOST)] approved the 'Climbing Up' project, in which nanomaterials research was emphasized. In the early 1990s, several Chinese academic research organizations collaborated to accelerate research efforts in China on nanomaterials science, while MOST's 973 Program (1999) was aimed at supporting basic research on nanostructures such as nanotubes. The 973 Program's significance lies in its emphasis on the standardization of procedures and assessment and test protocols, which tend to form the basic framework structure for regulatory considerations of nanomaterials [25]. 
Since 2002, when the China PR National Science Foundation produced a nanotechnology plan, nanotechnology has been recognized as a highpriority area by the Chinese government (Lee et al. 2011). In China PR's National Medium- and Long-term Science and Technology Development Plan (2006-2020), nanotechnology is one of four large projects explicitly mentioned in the plan as a priority mission area, and as a key frontier technology, over the next 15 years [45]. The 2009 national research plan set aside 0.15 billion RMB (yuan) for nanotechnology; Appelbaum and Parker conclude that, with respect to nanotechnology, China is closing the gap that once existed between itself and the United States, Europe, and Japan [4].

Presently, there are more than 30 research organizations in China PR that have initiated research activities studying the toxicological and environmental effects of nanomaterials and nanoparticles [52], and 120 research organisations undertaking general research into nanoscience and nanotechnology ([13]: 101). The three major national centres for nanotech are the National Centre for Nanoscience and Nanotechnology (NCNST) in Beijing, the Nanocommercialisation centre in Tianjin, and the China Safety Lab, which comes under the auspices of the Chinese Academy of Sciences (CAS). ${ }^{3}$ The three areas of research, commercialisation, and safety to which these three centres are dedicated aptly indicate PR China's current foci.

In the view of Tang, Carley and Porter, the initial focus for China PR was regulatory support for significant research for technology commercialization and economic growth. However, a 2004 conference on biological and environmental nanoeffects and the launch of a program on the toxicological effects of nano suggested the start of a China PR nanosafety debate. As Qi argued, nanosafety research became 'an integral part of nanotechnology research' [39]. China has run two major 5-year projects: 'The Toxicological Effects of Carbon Nanomaterials' (20042008), and 'The Environmental Activity and Health Impact of Ambient Superfine Particle' (2006-2010). The China Nanosafety Lab, which examines environmental health and toxicology matters, is linked into a

\footnotetext{
${ }_{3}^{3}$ Professor Chunying Chen, Bilat-Silk (Bilateral Support for the International Linkage with China, FP7, 222800) roundtable on 9 November, 2011 at CASTED, Beijing, China PR.
}

larger network of research centres for nanosafety. From its inception in 2008 with the establishment of the Laboratory for Biomedical Effects of Nanomaterials and Nanosafety, it has worked with the Research Centre for Cancer Nanotechnology (at the Tianjin Cancer Hospital), the Lab for the Bio-environmental Effects of Nanomaterials and Nanosafety (established by the Institute of High-Energy Physics, or IHEP, and the NCNST), and the nano-biological research group at IHEP.

The debate has intensified after a nanoparticle exposure accident in a poorly ventilated Chinese paint factory in August 2007, in which seven workers contracted lung disease- two died [43]. After this incident, 'Chinese policymakers shifted focus to the risk management aspects of nanotechnology' [46]; a largescale program began in 2011 for example on factory monitoring for worker exposure. The f 2007 incident realised several questions about whether the casual link between exposure and pulmonary illness can in fact be proven.

While the effects of nanoparticles on humans and on the environment have been the priority, there has also been acknowledgement of other societal concerns. The Director's Note in the 2007-8 Annual Report of the China Nanosafety Lab for example states that the lab 'must take an extensive and deep research of nanotechnological influence on human health, environment, and social problems' [20].

In terms of oversight, the Ministry of Science and Technology is generally responsible for S\&T policies and the planning and execution of national S\&T plans and programs. It is also responsible for drafting rules, regulations and laws, and has responsibility for policy implementation. MOST plays an important role in distributing research funds including projects implemented by other agencies. MOST is supported by the Chinese Academy of Science and Technology for Development (CASTED), an institution that undertakes foresight and strategic research to provide macro-level advice and assistance for designing S\&T plans. CASTED contains ISTS, the Institute of Science, Technology and Society, which conducts several large-scale surveys on matters such as food safety risk, the public image of scientists etc. One of its three main areas of interest is the social environment of innovation. Thus while initially emphasis was solely on applied research in the nanotechnology field, new research teams such as the Institute of Policy and 
Management (IPM), part of the Chinese Academy of Sciences, have now been formed. ${ }^{4}$

\section{Nanoethics (China PR)}

China PR is beginning to face a range of nanotechnology governance challenges, such as addressing low public awareness, developing a robust risk research strategy, and implementing an effective oversight system, very similar to those confronting the EU. One general concern that has emerged is whether the public outside of China, especially the United States public, will trust Chinese-made nanoproducts in the wake of scandals involving tainted pet food, toothpaste, children's toys, and drugs. Michelson asks:

...can China find an effective way to move up the value chain and transition from manufacturing cheaper, low-end products to more expensive, high-end, nano-engineered goods? .... In the wake of more immediate environmental and public health concerns currently affecting China, from managing pollution, to depleted fisheries, to lack of access to healthcare, how will disruptive challenges posed by nanotechnology exacerbate or enhance these existing problems? Will China have the resources and the luxury of proactively addressing environmental and health risks posed by nanotechnology in addition to these ongoing challenges? ([32]:406).

The concern with nanoethics started later in China PR than in the EU, not only due to the development delay in technology, but also perhaps because of differences in emphasis on societal concern. In other words, China PR's belief in social progress through scientific development means that economic impetus, rather than societal concern, is the major driver and overriding impetus behind new technologies.

Choi has argued in 2003 that the following issues should be considered by Asian nanoethicists:

- Equity between those with access to technology and those without, both in terms of developed versus underdeveloped countries, as well as internally within rural and urban populations

\footnotetext{
${ }^{4}$ Professor Zhenzhen Li, Bilat-Silk (Bilateral Support for the International Linkage with China, FP7, 222800) roundtable on 9 November, 2011 at CASTED, Beijing, China PR.
}

- Privacy issues in Confucian systems (there has long been debate over the individual's right to privacy of medical information, for example)

- Gender issues (as the majority of nanoscientists are male)

- Brain implants and other issues relating to human enhancement

- Undue inducement, for human subjects in nanomedical clinical trials for example

- Military uses of new technologies

- Environmental toxicity, including how effectively nanowaste can be managed in space-limited countries with large populations.

These issues, when compared to EU debates on nanoethics, are quite similar (see Table 1 in the Appendix). Choi's recommendations are:

- Better ethics education in schools

- More dialogue between research institutes, granting bodies, and the public on ethical issues

- Bioethics education for medical practitioners

- More ELSI research funding

- More international cooperation and knowledge sharing

- Establishing NGOs to work primarily on ethical concerns related to technology development

- Establishing independent watchdogs for nanotechnology-related policy and research for government and business [10].

In China PR, CASTED has called for S\&T ethics courses in universities on the basis that education is the main channel for building a culture of S\&T values. Tsinghua University for example has an engineering ethics course. Several Chinese universities (Dalian Technology University, Beijing University, as well as Renmin, Hunan, and South-East), have research centres based around S\&T ethics. CASTED is involved in the GEST (Global Ethics in Science and Technology) project as part of the EU $7^{\text {th }}$ framework. GEST aims to explore the role of ethics in science and technology policy as it is currently developing both in Europe and in the two main global emerging economies of China and India. ${ }^{5}$

What of the Chinese debate? Compared to the reasonably extensive debate in the $\mathrm{EU}$, it is fairly low-key (see Table 2). Chinese commentators have,

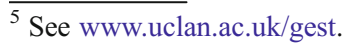


Table 1 Categories of nanoethics issues in the East and West (China PR/EU)

\begin{tabular}{|c|c|c|c|}
\hline Issue & Pro (West) & Contra (West) & Contra (East) \\
\hline Enhancement & $\begin{array}{l}\text { A new and improved 'better human' with } \\
\text { increased longevity, fewer health } \\
\text { issues, possibly even enhanced } \\
\text { intelligence through IT/cognitive/ } \\
\text { biological convergence (NBIC) }\end{array}$ & $\begin{array}{l}\text { Creation of new elites (enhancement } \\
\text { only for the rich); loss of 'humanness' } \\
\text { ('nanoself'); increased longevity } \\
\text { means more pressure on resources }\end{array}$ & $\begin{array}{l}\text { IT/neurobioengineered } \\
\text { implants; equity of } \\
\text { access }\end{array}$ \\
\hline Military use & $\begin{array}{l}\text { Better wound care; more precise targeting } \\
\text { (less collateral damage) }\end{array}$ & $\begin{array}{l}\text { Leading to 'unequal wars'; creation } \\
\text { of 'supersoldiers' }\end{array}$ & $\begin{array}{l}\text { Military uses of } \\
\text { nanotechnology, } \\
\text { i.e. weapons }\end{array}$ \\
\hline Health risks & $\begin{array}{l}\text { Health amelioration, better drugs; } \\
\text { portability - better health care for remote } \\
\text { and rural communities; economic benefit } \\
\text { of reduced health care spending }\end{array}$ & $\begin{array}{l}\text { Threats to human health through dermal } \\
\text { exposure or inhalation or ingestion of } \\
\text { nanoparticles }\end{array}$ & $\begin{array}{l}\text { Threats to human health } \\
\text { through dermal exposure } \\
\text { or inhalation or ingestion } \\
\text { of nanoparticles }\end{array}$ \\
\hline $\begin{array}{l}\text { Environmental } \\
\text { harm }\end{array}$ & $\begin{array}{l}\text { Amelioration of environmental issues such } \\
\text { as non-potable groundwater }\end{array}$ & Threat to environmental health & $\begin{array}{l}\text { Threat to environmental } \\
\text { health; nanowaste and } \\
\text { space limitations }\end{array}$ \\
\hline Access/Equity & $\begin{array}{l}\text { General economic benefit globally in terms } \\
\text { of new products that will affect the } \\
\text { construction, energy, medtech and IT } \\
\text { industries }\end{array}$ & $\begin{array}{l}\text { Increased (nano)divide between devel- } \\
\text { oped and developing countries-issues } \\
\text { of distributive justice, global benefit }\end{array}$ & $\begin{array}{l}\text { Nanodivides within Asian } \\
\text { countries with large rural } \\
\text { and/or poor populations; } \\
\text { undue inducement }\end{array}$ \\
\hline Privacy & $\begin{array}{l}\text { Smaller and less obtrusive surveillance } \\
\text { devices; privacy of medical information; } \\
\text { greater security }\end{array}$ & $\begin{array}{l}\text { Increasingly miniaturised surveillance } \\
\text { devices lead to potential loss of civil } \\
\text { liberties, increased surveillance of } \\
\text { average citizens }\end{array}$ & \\
\hline
\end{tabular}

albeit in very brief fashion, noted toxicity risks such as damage to human health and the environment. However, some have introduced other issues. Ying likens nanotechnology to GM foods issues, implying a public acceptance issue, albeit only in passing [51]. Li, while mentioning environmental problems (giving the example of a Korean company that stopped production of a certain washing machine after pressure from Friends of the Earth) notes wider issues such as increased lifespan due to nanomedical development, i.e. the societal impact of longer-living, healthy citizens [30]. Wang notes potential problems relating to consumer rights (in the context of food and cosmetics products), as well as privacy and intellectual property rights issues. [48]. Fan, perhaps the most 'Western' in his writing on nanoethics, notes that 'compared with safety issues, research on ethical, legal and social issues should be strengthened', as should dialogue between the scientific community and the public [17]. As Cao and Li note, the shift in approach from a predominately science-community-based approach to nanotechnology policy and regulation, to one that includes social scientists as well, is still ongoing [9].

\section{Public Participation in the East}

The Thai government is reviewing the country's first strategy plan on nanotechnology safety and ethics, drafted in 2011. The Thai National Nanotechnology Center, NANOTEC, held a public hearing session in Bangkok in 20122 where stakeholders from various sectors were given an opportunity to voice their opinion on the draft. (Nanosafety labeling can be expected in 2016, when regulations on nano safety and ethics are fully enforced. $)^{6}$ In South Korea NGOs play an active role in bringing together scientists and the public. The 'STS' or Science-Technology-Society approach informs the Korean school curriculum, just as in Japan schoolchildren are given guidelines to bioethics [11]. In Taiwan, the National Strategic Plan for Responsible Nanotechnology, reflects the government's ambition to realize the full potential of nanotechnologies while acknowledging the possibly harmful societal impacts from nanotechnologies.

\footnotetext{
${ }^{6}$ Thailand pushing forward on Nanosafety regulations', January 18, 2011. Retrieved 12 December, 2011, from http://www. biospectrumasia.com/content/180111THA15262.asp.
} 
Table 2 A comparison of nanoethics environments in the EU and China

\begin{tabular}{|c|c|c|}
\hline & Europe & Asia (China) \\
\hline Social values: & Autonomy, individual human rights & Harmony, community \\
\hline \multirow[t]{4}{*}{$\begin{array}{l}\text { Attitude towards S\&T and } \\
\text { scientists: }\end{array}$} & $\begin{array}{l}\text { - Public differentiation between technologies i.e. } \\
\text { differing risks for nuclear, nano, GM } \\
\text { - Risk v benefit }\end{array}$ & $\begin{array}{l}\text { - Innovation is always good } \\
\text { - Tao governs technology; }\end{array}$ \\
\hline & \multirow[t]{3}{*}{$\begin{array}{l}\text { - Post-Fukushima emphasis on confidence/or lack } \\
\text { thereof in government, according to how it han- } \\
\text { dles S\&T crises }\end{array}$} & - Harmony between tian (nature) and ren (human) \\
\hline & & $\begin{array}{l}\text { - Trust in government (although this may be starting } \\
\text { to decrease due to food scandals) }\end{array}$ \\
\hline & & - Concern with social responsibility of scientists \\
\hline GM food as example & GM 'backlash' in many EU countries & $\begin{array}{l}\text { GM issue products sold in China-but must be } \\
\text { labelled; public distrust }\end{array}$ \\
\hline $\begin{array}{l}\text { Which nanoissues are seen } \\
\text { as significant? }\end{array}$ & $\begin{array}{l}\text { Toxicity (human and environmental), } \\
\text { enhancement, military use, privacy, distributive } \\
\text { justice }\end{array}$ & $\begin{array}{l}\text { Safety; science governance; global security an } \\
\text { emerging issue, as is public knowledge deficit }\end{array}$ \\
\hline Economic benefit focus & Better drugs e.g. for cancer treatment & General economic driver \\
\hline $\begin{array}{l}\text { Consumer confidence in } \\
\text { new products }\end{array}$ & $\begin{array}{l}\text { EU } 2013 \text { mandatory labelling of cosmetics that } \\
\text { contain nanoparticles }\end{array}$ & $\begin{array}{l}\text { New equals good; and 'nano' are pluses for } \\
\text { marketeers }\end{array}$ \\
\hline $\begin{array}{l}\text { Institutes leading } \\
\text { nanoresearch }\end{array}$ & $\begin{array}{l}\text { EC Action Plan on Nanotechnology 2005-9 } \\
\text { (ongoing implementation reports in 2007, 2009) }\end{array}$ & $\begin{array}{l}\text { 2000: National Steering Committee for Nanoscience } \\
\text { and Nanotechnology established in China; 2003; } \\
\text { nanosafety lab }\end{array}$ \\
\hline $\begin{array}{l}\text { Seminal reports that have } \\
\text { triggered nanoethics } \\
\text { concerns: }\end{array}$ & $\begin{array}{l}\text { Greenpeace report, the Royal Society and Royal } \\
\text { Academy (RS/RAE), report and insurance } \\
\text { company Swiss Re's report (2003-4) }\end{array}$ & \\
\hline $\begin{array}{l}\text { Role of NGOs in S\&T } \\
\text { advising: }\end{array}$ & Strong in terms of TA and policymaker liaison & $\begin{array}{l}\text { NGOs small in size and relatively weak in } \\
\text { organisational capacity, no policy-effecting } \\
\text { channels }\end{array}$ \\
\hline TA infrastructure & Varied across Europe & Established for about 10 years \\
\hline $\begin{array}{l}\text { Participatory technology } \\
\text { assessment }\end{array}$ & $\begin{array}{l}\text { Many European dialogue initiatives, plus } \\
\text { individual (national) initiatives in Germany, the } \\
\text { Netherlands, UK etc. }\end{array}$ & $\begin{array}{l}\text { - Not yet-planned for } 2012 \\
\text { - Consensus conference } 2008 \text { on GM food-with } 25 \\
\text { participants; from that negative experience } \\
\text { scientific community focussed on Code of Conduct } \\
\text { as way of promoting acceptance }\end{array}$ \\
\hline Global view and & On standards & On standards \\
\hline cooperation & & Increasing awareness of Western debates \\
\hline $\begin{array}{l}\text { International bodies-IRG, } \\
\text { GHS, ISO, REACH, } \\
\text { Comest, OECD etc. }\end{array}$ & EU representatives on all & China PR active on ISO and REACH \\
\hline Codes? & EU Code for responsible nanoresearch & $\begin{array}{l}\text { - MOST S\&T general guidelines applied to } \\
\text { nanoresearch from beginning }\end{array}$ \\
\hline & & $\begin{array}{l}\text { - CAS Special committee on science ethics } \\
\text { examined scientific misconduct in } 2010-11 \text { and } \\
\text { has ethics of emerging technologies as next focus } \\
\text { (GM and nano) }\end{array}$ \\
\hline & & - Code predicted in 2012 \\
\hline
\end{tabular}

Much of this information was taken from roundtable discussions in Beijing 9-11 November, 2011

(The combination of nanotechnology and Chinese herbal medicine is a newly emerging field sought after by the Taiwanese industry, and is leading to some ethical discussion, most notably around intellectual property issues [23]). In the most recent Taiwanese Science and Technology Development Plan [34], 
nanotechnology is given specifically notable attention. Two passages in the plan stand out and provide particular insight in to the government's outlook on technology policy:

The public's distrust of science and technology is at least partially attributable to insufficient relevant information and awareness. Appropriate ethical and legal responses may be needed to deal with the risks posed by new technologies to life and the environment, and the ethical conflicts they cause...Unlike such areas as medical biotechnology, where ethics committees have been established, little has been done thus far to address research ethics in many new technological fields in Taiwan (such as genetic technology and nanotechnology). ${ }^{7}$

The issue of 'public distrust' is one that China PR has been starting to face in terms of GM food. Whilst expert Technology Assessment (TA) has a history in China PR, it tends to be dominated by natural scientists with little background in social issues. Information delivery, rather than debate, is more likely to be the aim of any survey, as in the Dalian Technical University 2008 nanotechnology survey (of 1,000 samples). This survey concluded that the Chinese public had greater awareness of nano than the US. CASTED conducted a survey in three cities in 2008 on GM food, concluding that public non-awareness of the subject was widespread (while noting variations according to city size and level of tertiary education).

While TA is known, participatory Technology Assessment (pTA) is a relatively new development, and has so far been limited in China PR to a consensus conference on GM food in 2008, one with 25 participants. This conference was organised by CAS, and the S\&T commission for Xicheng District, Beijing. Called 'Science and Community 2008 - GM foods', the aim was to recruit volunteers from varied socioeconomic backgrounds; 38 applications were received, from which 20 public participants were chosen (plus 5 experts on GM foods and health, ethics and society, consumer choice and legislation). The final

\footnotetext{
${ }^{7}$ National Science and [34], National Science Council, Executive Yuan, Taiwan, http://web1.nsc.gov.tw/public/Attachment/ 91214167571.PDF, p. 60; See also Mika Purra \& Noah Richmond, 'Mapping Emerging Nanotechnology Policies and Regulation: The Case of Taiwan' [38]. Retrieved 28 December, 2011 from http://www2.1se.ac.uk/internationalRelations/ centresandunits/regulatingnanotechnologiesnanopdfs/ Taiwan2010.pdf.
}

document report showed more uncertainty postconference than before about the relationship between the public and experts, as some participants began to 'modify their submissive position towards the experts' while remaining supportive towards the government. The primary result of the conference, it was concluded, was clarification of the need for more public education. $^{8}$

GM food, nanotechnology, stem cell technology and IT, are still seen as the major areas of attention for the science community, rather than the public, but there is a growing realisation amongst the scientific community that a wider approach, involving greater awareness of societal concerns, and potentially also pTA, is required. A November 2011 workshop on academic morality and scientific ethics to facilitate integration between the natural and the social sciences suggest the China PR scientific community's realisation that the social sciences have an integral role to play in technology evaluation and implementation.

\section{EU Nanohistory, Nanoregulation, Nanopolicy and Nanoethics}

China PR is not alone in its belief that nanotechnology is an economic driver: In terms of the 2004 Lisbon Strategy, now replaced by the Europe 2020 strategy, Europe has clarified stated its aim of being a highly competitive knowledge-based global economy. ${ }^{9}$ A focus on nanotechnologies was seen as a key part of this strategy. Thus the formation of the 2004 European Nano-Electronics Initiative Advisory, in terms of which European technology companies such as Philips, Nokia, Ericsson, AMD, and IBM decided that if Europe wanted to lead the world, it would need to invest at least 6 billion euro per year to switch from micro to nanoscale electronics. A public-private partnership charged to develop and implement a European nano-electronics research agenda first met in 2004. Its goals include: supporting research and investment in nano, speeding up innovation and productivity, the facilitation and acceleration of market penetration of new technologies, aligning research/technology with European policies and regulatory frameworks, and

\footnotetext{
${ }^{8}$ Du Peng, 'The Practice of TA in China' (Chinese Academy of Science), NCSTE presentation on 10 November, 2011, Beijing.

${ }^{9}$ Retrieved 15 December 2011 from http://ex.europa.eu/ europe2020/targets/eu-targets/index_en.htm. See also http:// www.eu2020regions.eu/node/6, retrieved February 2, 2012.
} 
increasing public awareness, understanding, and acceptance of nanotechnologies ([1]: 238-9). A later group, The European Network of Excellence (Nano2Life) 2004-2008 involved nearly 200 scientists, 23 research organizations, and 12 countries, and has joined with industrial partners to identify regional centers, disciplines, and expertise available for collaboration. Goals included developing joint research projects on four major technical platforms: functionalisation, handling, detection, and integration of nanodevices.

The history of EU nanoregulation should be placed in the context of biotechnology regulation, which dates back to the establishment in 1991 of a European Commission Group on Ethics in Science and Technology. The Group was constituted to advise the Commission on how to exercise its powers as regards the ethical aspects of biotechnology. It noted in its general report examples of embedded ethics into policy such as the Science and Society Action Plan (2001), the Action Plan Life Sciences and Technology (2007), as well as legislative activities such as directives governing clinical trials, patents, data protection, the use of animals in experimentation, and the EU Chemical, Biological, Radiological or Nuclear (CBRN) Action Plan (2009). ${ }^{10}$ The EGAIS (Ethical Governance of Emerging Technologies) project, funded by the 7th Framework Programme (Science in Society) for example, has as its mission 'to overcome the existent limitations of the current approaches to ethical governance in projects with technical development'. ${ }^{11}$ The European Commission's Directorate-General and Services involved in nanotechnology number over a dozen, including 7 agencies for risk evaluation. ${ }^{12}$

EU awareness of nanotechnology issues began in earnest in 2003, after discussion on potential risks by the European Parliament's Green Party, [36] and after the publication of the 2001 National Nanotechnology Initiative (NNI) in the USA. In terms of the EU's 'framework' structures for funding research and

\footnotetext{
$\overline{{ }^{10} \text { Retrieved } 15}$ December 2011 from http://ec.europa.eu/ european_group_ethics/docs/GAR\%20EGE\%202005-2010_ WEB.PDF.

${ }^{11}$ Retrieved 15 December 2011 from http://www.egaisproject.eu>. EU ethics advising has seen (according to Cordis, the EU's information repository) an increased level of funding allocated in terms of the EU's 7th Framework Programmes (2007-2011).

${ }^{12}$ The full list can be seen at the following website: http:// ec.europa.eu/nanotechnology/links_en.html.
}

technological development, Framework Programme 6 (FP6) (2002-6) indicated that nanotechnology had become a research priority, possibly stimulated by a need to compete with the USA. FP6 was introduced with policy objectives to enhance innovation, and to 'change the European research landscape through the introduction of the integrated European Research Area (ERA), and create sustainable growth, increased employment and greater social cohesion' [37].

The 3 EC Scientific Committees set up in 2004 were: SCCS (the Scientific Committee on Consumer Safety), which oversees nanomaterials in consumer products; SCER (the Scientific Committee on Health and Environmental Risks), which looks at nanotechnology in food, as well as medical and environmental issues, and SCENHIR (the European Commission's Scientific Committee on Emerging and Newly Identified Health Risks), which looks at methodologies for risk assessment of new technologies such as nanotechnology. ${ }^{13}$

The EC's Action Plan on Nanotechnology (2005), as well as considering possible adverse effects on health and the environment, also highlighted the ethical issues of nanotechnology's potential to contribute towards the Millennium Development Goals. As well as discussing public participation and education, the Plan encouraged internationally cooperative work on nanoregulation. In 2007, the European Commission accepted the first implementation report (2005-2007) of the Action Plan. The second implementation report was adopted in 2009, with the statement that 'efforts to address societal and safety concerns must be continued to ensure the safe and sustainable development of nanotechnology., 14

The European Group on Ethics in Science and New Technologies (EGE) set up in 1991, has a strictly advisory role, with a global outlook rather than a specifically EU one (Heemeren). The EGE's 2006 Opinion 21 paper underlined 'the vital importance of addressing concern for safety with respect to ... nanotechnology in general'. It advocated, in regards to nanomedicine, the need to 'establish measures to verify the safety of nanomedical products', and issues of military usage of nanotechnology, enhancement,

\footnotetext{
$\overline{{ }^{13} \text { Retrieved } 18}$ December 2011 from http://ec.europa.eu/health/ archive/ph_risk/committees/04_scenihr/docs/scenihr_o_ 023.pdf.

${ }^{14}$ Retrieved 18 December 2011 from http://eur-lex.europa.eu/ LexUriServ/LexUriServ.do?uri=COM:2009:0607:FIN:EN:PDF.
} 
economic equity and animal testing. ${ }^{15}$ The EGE group has been referred to as 'largely unknown', however, according to a public (admittedly global rather than EU) survey. ${ }^{16}$ Another EU advisory group is ETAG, The European Technology Assessment Group, which runs projects on the potential environmental, health and safety risks of engineered nanomaterials (such as their project on chemical risk in 2006, and on human enhancement in 2008-9).

The High Level Expert Group (HLEG) was convened by the EC in 2010 to develop possible policy measures to promote the industrial take-up of new technologies by EU industries. The HLEG's nanotechnology report suggests two views of convergence, one implying mutually enabling technologies, and the other a culture of promotion of enhancement (Foresighting: 2; de S. Cameron, [12]: 29). The interesting parts of the HLEG document are its advocation of both moral pluralism, and of the need for ethics to be an intrinsic part of technological advances. Stating that technological development must "harmonize with the values of diversity, social justice, international security, and environmental responsibility', it recommends preparation of an international 'code of good conduct'. ${ }^{17}$

The European Project NanoCode, a 2-year multistakeholder dialogue providing input to the European Code of Conduct for Responsible Nanosciences \& Nanotechnologies Research commenced in January 2010, with the aims of monitoring stakeholder input and suggesting revisions to this Code of Conduct (EUCoc). ${ }^{18}$ In 2011, its report on stakeholder attitudes towards the Code concluded that awareness of the code 'was limited to a community of selected key experts' and was not 'embedded in the everyday life' of the large majority of researchers in Europe. The report also concluded that few governments seemed able to communicate the Code's principles to

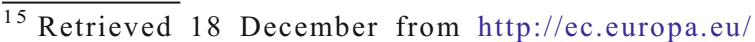
nanotechnology/pdf/swedish-presidency-event/martinho_de_ silva.pdf.

16 'Report on the European Commission's Public Online Consultation. Towards a Strategic Nanotechnology Action Plan (SNAP) 2010-2015', p. 4. Retrieved 18 December from http:// ec.europa.eu/research/consultations/snap/report_en.pdf.

${ }^{17}$ Retrieved 18 December from http://www.ntu.no/2020/final report-en.pdf, p. 9, p. 54.

${ }^{18}$ Retrieved 18 December from http://www.innovationsgesellschaft.ch/media/archive2/publikationen/nanocode-newsletter2.pdf.
}

stakeholders effectively. ${ }^{19}$ An issue raised by stakeholders has been that of the 'lack of teeth' of voluntary codes such as this, which have not been widely adopted-although some research institutions claim that their own codes are sufficient. This raises the further issue of whether the Code should be promoted as the 'one and only', or allowed to coexist with the institutional guidelines. Suggestions on how to give the Code some 'teeth' ranged from the development of tailor-made codes i.e. specific for nano-companies, a 'naming and blaming' in case of non-compliance, linking compliance to public funding, and incorporation of the Code into the EC Research Framework as a guideline.

In 2008, the European Commission (Regulatory Aspects of Nanomaterials) concluded that existing EU regulatory frameworks covered in principle the potential health, safety and environmental risks related to nanomaterials, and stressed that the protection of health, safety and the environment needed to be enhanced mainly by improving the implementation of current legislation. In answer to this communication, however, the European Parliament declared the EC's statement to be misleading and 'one-dimensional' ${ }^{20}$

\section{Nanoethics (EU and the West)}

Whereas nanoethics in China PR is an emerging field, and still remains focused to a degree on toxicity risk, Western commentators have a wider view of potential NELSI issues. A 2008 summary of 'nanorisks'- or 'nanopportunities', depending on one's level of optimism - include ownership of technology and accountability; privacy (increasingly undetectable nanoscale devices); human enhancement, and public involvement in technology development ([50]:17). BennettWoods notes issues of human dignity and also of fidelity, or competing loyalties - security versus privacy or profit versus equity-as well as social justice, military and security implications, and informed consent to new technological ideas ([6]:5). Spagnolo and

\footnotetext{
$\overline{{ }^{19} \text { Retrieved } 18}$ December from http://www.nanocode.eu/files/ reports/nanocode/nanocode-consultation-synthesis-report.pdf (p. 6).

${ }^{20}$ European Parliament: Report on regulatory aspects of nanomaterials (2008/2208(INI)). Committee on the Environment, Public Health and Food Safety. A6-0255/2009. Retrieved 3 February, 2012 from http://nano.foe.org.au/node/329.
} 
Daloiso, arguing that nanomedicine is the most useful application of nanotechnology, summarise ethical issues as: toxicity, immunogenicity and biocompatibility, nanoparticle stability, human enhancement, privacy and integrity, and the shift from patient-doctor interaction to home-care technology used by the patient ([44]: 396). Schummer selects six areas of concern, including the more speculative areas of the increasing autonomy of machines, how nano should be controlled (the 'grey goo' scenario), and of biomedical application or enhancement. He also sees military applications, health and environmental risks, and the equity issue of developing countries, as well as the issue of intellectual property rights [41]. New nanoproducts may lead to a displacement of jobs and major changes in trade balances between countries; manufacturing in countries with weaker controls and subsequently exported worldwide may increase risk, and benefits may be unevenly distributed (leading to a so-called 'nanodivide'-[33]). More broadly, nanotechnology has been condemned for its potential to advance Western consumerism; little research has been aimed at products that might benefit the poor [31].

The West shares with China PR a strong concern however on toxicity risk. The effect of nanotoxins on humans, animals and the environment have yet to be determined, and laboratory studies have suggested some physical damage through the inhalation of nanoparticles, leading to the fear that nanotech might potentially be 'the next asbestos' ([2]:5). Nanoparticles have been alleged to damage DNA, negatively affect proteins, and cause cell death [28]. A study at the University of Rochester found that when rats breathed in nanoparticles, the particles settled in the brain and lungs, which led to significant increases in biomarkers for inflammation and stress response [8]. Mice studies have also found that nanoscale titanium dioxide, touted for use in many energy applications, can cause genetic instability [47]. A 2-year study at UCLA's School of Public Health found laboratory mice consuming nano-titanium dioxide showed DNA and chromosome damage [15]. Several types of engineered nanomaterials including titanium dioxide and carbon nanotubes are believed to produce pulmonary inflammation and fibrosis in animals [42], and even brain damage [35]. Nanoparticles may increase the risk of strokes [16]. There is concern that carbon nanotubes may potentially be 'the next asbestos' [2]. A further issue is that of environmental damage, as there is no clear view on how long nanoengineered materials may last in landfill, for example. (The table in Appendix A attempts to categorise these commonly agreed issues, and the arguments pro and contra their benefit, indicating the level of similarity between East and West.)

\section{Public Participation in the EU}

The UK government has stated that 'properly targeted and sufficiently resourced public dialogue will be crucial in securing a future for nanotechnologies' ([40]: para. 80). There have been several EU projects designed to increase public dialogue on the socioethical concerns of nanotechnology, such as Nanologue (2005-6), aimed at the facilitation of a Europewide dialogue among science, business and civil society about its benefits and potential impacts, or Nanobio-RAISE (2006-7) intended to bring together nanobiotechnologists, ethicists and communication specialists to anticipate and discuss societal and ethical issues, or Nanoplat (2009), aimed at the "points of intersection between the sphere of production on the one hand and consumers on the other. ${ }^{21}$ The SNAP global public consultation conducted from 18 December 2009 to 19 February 2010, concluded optimistically that, there was a'good or very good perception of EU governance related to nanotechnologies in terms of stakeholder consultation and setting research priorities' (SNAP: 4, 17), However, another EU project, framingNano (2008-2010), noted greater uncertainty about public acceptance of nanotechnology.

Individual EU members also have run dialogue initiatives; for example, in The Netherlands, 'NanoNed' allocates $15 \%$ of its budget to research on societal impact, ${ }^{22}$ while 'Nanopodium' (launched in December 2009 in The Netherlands) has as its mission the stimulation of public dialogue about the threats, opportunities and applications of nanotechnology. In Germany's 'NanoDialogue', representatives from the scientific world, the business community, environmental, consumer and women's associations, trade

\footnotetext{
$\overline{{ }^{21} \text { Retrieved } 18}$ December 2011 from http://nanobio-raise.org/ groups/editors/menus/main/activities/view; http:/www. nanoplat.org/?q=node/4.

${ }^{22}$ Retrieved 18 December 2011 from http://www.nanoforum.org/nf06 $\sim$ modul $\sim$ showmore $\sim$ folder $\sim 99999 \sim$ scc $\sim$ news $\sim$ scid 3743 .html?action=longview.
} 
unions, churches, ministries and authorities provide input in to the public debate on the opportunities and risks of using nanotechnologies.

However, despite the positive initiatives - and many more-listed above, the 2009 reflection on the seminal 2004 Royal Society report argued that more needs to be done in the field of public engagement. The report added that nanoparticles allegedly are being released into the environment and that in the view of one collaborator on the updated report, there has been no 'meaningful change in regulatory practice or social engagement in the UK' $([5]: 5,46)$.

\section{Global Collaboration}

...it is still necessary to set up a viable system based on the precautionary principle.....since research in the field of social and ethical evaluation of nanotechnology developments in China is not as advanced as in the USA and Europe, cooperation is important to avoid making similar mistakes and to promote the smooth development of nanotechnology ([13]: 106).

The major achievement of the EU nanoadvisory 'movement' has been the establishment of standards for working with nanomaterials. The CEN/TC 352 'Nanotechnologies' (established in 2005) to develop a set of standards, and the 2006 EC establishment of REACH-Registration, Evaluation, Authorisation and Restriction of Chemical Substances addressing the following aspects of nanotechnologies: classification, terminology and nomenclature; metrology and instrumentation, including specifications for reference materials; test methodologies; modelling and simulation; science-based health, safety and environmental practices; and nanotechnology products and processes. ${ }^{23}$

The second major achievement is the 2009 Code of Conduct for Responsible Nanosciences and Nanotechnologies Research, described as follows:

The recently released Code...developed by the European Commission is one code that is voluntary, but which has originated in a political sphere and which demands a higher level of accountability.... the code seeks to intervene at an earlier stage in the

\footnotetext{
$\overline{{ }^{23} \text { Retrieved } 21}$ December from http://www.cen.eu/cen/Sectors/ Sectors/Nanotechnologies/Pages/default.aspx.
}

development cycle of nanotechnologies, embedding principles of responsibility at the research stage. ${ }^{24}$

Given its recent focus on nanosafety, unsurprisingly China PR has published 15 nanotechnology standards since the establishment of its Committee of National Nanotechnology Standards (2005), which dealt mainly with risk assessment of nanoparticles. This focus translated into its international work on the global nanotechnology regulation bodies/projects, of which there are 9 major ones, including $\mathrm{REACH}$, already mentioned above. The other 8 are: (1) the International Council on Nanotechnology (ICON) [29]; (2) the European Standards Committee (CEN/TC352) Nanotechnologies (set up with the aim of providing an international standard $)^{25}$; (3) the Globally Harmonised Scheme for classification and labeling of substances (GHS); and (4) the International Standards Organization (ISO). The various ISO standards provide ways of evaluating risk; they are primarily methodological tools for industry players. However it should be noted that the ISO has a member list of 162 countries, including China, which has been involved in 707 standards - more than any other of the countries listed. ${ }^{26}$ (China PR hosted ISO/TCC 229 in 2008 in Shanghai).

The 5th is the International Council on Risk Governance (IRGC), established in 2003, at the initiative of the Swiss government; its Council has members from 13 different countries, one of which is China. ${ }^{27}$ The final 3 are: The Commission on the Ethics of Scientific Knowledge and Technology (UNESCO/ COMEST) and two OECD nanotechnology working parties, WPN (the Working Party on Nanotechnology), with a focus on governance, and WPMN (the Working Party on Manufactured Nanomaterials), an international forum for the further development of test

\footnotetext{
$\overline{{ }^{24} \text { Retrieved } 21}$ December from http://www.framingnano.eu/ index.php?option=com_content\&task=view\&id=147\&Itemid=1.

${ }^{25}$ Retrieved 21 December from http://www.ecostandard.org/ downloads_a/cen-overview-std-nanotech-sept07.pdf; see point 2.1.1. It includes analysis of national standards bodies in the EU, UK, North America, Japan, China, and Korea as well as brief mention of international standards bodies such as the E56 Committee on Nanotechnology, which rather vaguely lists as one of its activities 'as the maintenance of appropriate global liaison relationships with activities related to nanotechnology'.

${ }^{26} \mathrm{http} / / / w w w . i s o . o r g /$ iso/about/iso_members.htm

${ }^{27}$ Retrieved 21 December from http://www.irgc.org/irgc/about irge
} 
guidelines and strategies needed for the proper implementation of regulation.

The OECD and UNITAR jointly held AwarenessRaising Workshops on Nanotechnology/Manufactured Nanomaterials for Developing and Transition Countries, held in Beijing, Abidjan, Lodz, Kingston, and Alexandria. In addition to the formal structures discussed briefly above, there have been international dialogues such as that on the Responsible Research and Development of Nanotechnology (established by The European Commission in 2004), and the Meridian Institute's Global Dialogue on Nanotechnology and the poor, which has resulted in a paper, a news service, and two workshops (India and Brazil, 2006 and 2007). ${ }^{28}$

A November 2011 project on research methods for managing the risk of engineered nanoparticles and engineered nanomaterials, the MARINA project, under FP 7 of the EC, will run for 4 years and involve the collaboration of 47 different scientific and industrial partners, including China PR.

There are also individual joint country agreements, such as the $2002 \mathrm{EU} / \mathrm{China}$ co-operation agreement in the field of material sciences. This agreement facilitates the participation of Chinese research organisations, including companies, in European research projects with Chinese funding and vice versa. In addition, the EU and China have a joint agreement to exchange data relating to safety testing in order to boost research into consumer safety respective to nanotechnology products.

China's regulatory regime for the management of nanotechnology chemicals will likely manage risks comparable to those identified under the EU's REACH regulation, and in this context, in 2009, the government revised the chemical substance rules in order to incorporate risk assessment, risk management and data submission requirements, similar to REACH ([25]:11-12).

\section{Conclusion: The Nano Environment in China PR Versus in the $\mathbf{E U}$}

Although there are obvious economic drivers behind the development of nanotechnology in both countries,

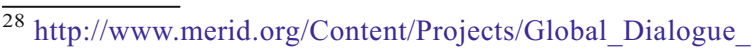
on_Nanotechnology_and_the_Poor.]aspx
}

the difference is in the degree of account taken of public concern, and the greater emphasis on development over social concerns in China PR. In the latter, industry employs the label of 'nano' as a plus point when advertising nanoproducts, whereas in Europe there is concern about nanolabelling, as well as more vocal consumer movements. However, the current food debate in China may signify a turning point in the perception of scientific development, and a need to accelerate public debate. The focus in China is currently on the responsibility of the scientist; in the EU it is on government accountability to the public-yet one might risk the prediction here that ultimately this will also become a governmental issue in China, since individual responsibility alone cannot guide S\&T development.

Whereas the official debate on benefits and risks is not markedly different in both areas, the public debate in China PR lags behind the EU. This is partly due to the fact that the public in China PR appears currently more concerned about GM food, and also to a lack of channels for public participation in China PR.

Yet public participation is globally seen as increasingly integral to governmental decision making, particularly given the economic effects of product boycotting, and China PR will arguably soon (and perhaps already is in terms of GM food) face this inevitable issue. The two regions are converging.

Acknowledgements The author gratefully acknowledges assistance from UCLan in terms of a travel grant for the 3-day Beijing trip during which much of the information presented in this article was garnered. Thanks go to Dr Miltos Ladikas (UCLan) for arranging the Beijing discussions, and for commenting on the draft of this article. Professor Doris Schroeder (UCLan) also assisted with revision and editing. I am also very grateful to Associate Professor Ma Ying, CASTED, for supplying me with several recent articles on nanoethics, and to my translators Yvonne Yu, Sissi Wang, and Rocky Liang, for assisting in their decoding.

\section{References}

1. Adams W, Williams L (2006) Nanotechnology demystified. McGraw-Hil, Blacklick, pp 238-239

2. Anderson A, Peterson A, Wilkinson C, Allen S (2009) Nanotechnology, risk and communication. Palgrave, Basingstoke

3. Andorno R (2009) Human dignity and global rights as a common ground for a global bioethics. J Med Philos $34: 223-240$ 
4. Appelbaum RP, Parker RA (2007) Innovation or imitation? China's bid to become a global leader in nanotechnology. Retrieved from http://www.cns.ucsb.edu/index.php? option $=$ com_remository $\&$ Itemid $=100 \&$ func $=$ select $\& i d=3 P$

5. Beacon or a landmark? Reflections on the Royal Society/ Royal Academy of Engineering Report: Nanoscience and nanotechnologies: opportunities and uncertainties (200). The Responsible Nano Forum, p 5, p 46

6. Bennett-Woods D (2008) Nanotechnology: ethics and society. CRC Press, New York

7. Berne RW (2006) Towards the conscientious development of ethical nanotechnology. Sci Eng Ethics 10:627-638

8. Buzea C, Pacheco I, Robbie K (2007) Nanomaterials and nanoparticles: sources and toxicity. Biointerphases 2(4): MR17-71

9. Cao N, Li S (2010). The development of China's nanotechnology needs allies in humanities and social sciences. Chinese Social Sciences Today, 25th September, 2010. http:// sspress.cass.cn/newspaper/paper.aspx? Id=1000129

10. Choi K (2003) Ethical issues of nanotechnology development in the Asia-Pacific region, regional meeting on ethics of science and technology, 5-7 November 2003, Bangkok. Retrieved from http://www2.unescobkk.org/ elib/publications/ethic_in_asia_pacific/327_ 376NANOTECH.PDF

11. Choi K (2007) Public engagement and education for ethics in nanotechnology. In: ten Have HAMJ (ed) Nanotechnologies, ethics, and politics. UNESCO, Paris, pp 181-204

12. de S Cameron NM (2007) Ethics, policy, and the nanotechnology initiative: the transatlantic debate on converging technologies. In: de S Cameron NM, Mitchel E (eds) Nanoscale. Wiley, pp 27-42, p 29

13. Decker M (2009) Dealing with nanoparticles: a comparison between Chinese and European approaches to Zhenxing nanotechnology. In Ladikas M (ed) Embedding society in science and technology policy. European and Chinese perspectives. European Commission, pp 91-124

14. Doubleday R (2007) Risk, public engagement and reflexivity: alternative framings of the public dimensions of nanotechnology. Health Risk Soc 9(2):211-227

15. Elder A (2006) Tiny inhaled particles take easy route from nose to brain. Retrieved from http://www.sciencenewsden.com/ 2006/tinyinhaledparticlestakeeasyroutefromnosetobrain.shtml

16. Evans D (2007) Ethics, nanotechnology and health. In: ten Have HAMJ (ed) Nanotechnologies, ethics, and politics. UNESCO, Paris, pp 125-154

17. Fan C (2010a) Ethical environment of nano-science-Presentation Transcript, 3rd International Workshop on Innovation and Performance Management, 1-4 July, 2010, University of Kent

18. Fan R (1997) Self-determination vs. family determination: two incommensurable principles of autonomy. Bioethics 11-9, 309-22, p 310

19. Finkler K (2008) Can bioethics be global and local, or must it be both? J Contemp Ethnogr 37:155-179

20. Forefront (2007-9). Annual Report, Director's Note

21. Friedman HB (1997) Human values and the design of computer technology. Cambridge University Press, New York

22. Gaskell G, Thompson P, Allum N (2002) Worlds apart? Public opinion in Europe and the USA. In: Bauer MW,
Gaskell G (eds) Biotechnology-the making of a global controversy. Cambridge University Press, Cambridge, p 386

23. Hsaio J-H (2010) Nanotechnology meets Chinese herbal medicine: an introduction to the patenting of nano based Chinese herbal medicine in Taiwan. Nanotechnol Law Bus 7(1):80-96

24. Hu W, Chen K (2004) Can Chinese consumers be persuaded? The case of genetically modified vegetable oil. AgBioForum 7(3):124-132, Retrieved from http:// www.agbioforum.org

25. Jarvis D, Richmond N (2010) Mapping emerging nanotechnology policies and regulations: the People's Republic of China, working paper (April 2010). Retrieved from http:// www.spp.nus.edu.sg/docs/wp/2010/wp1005.pdf

26. Jasanoff S (2004) States of knowledge: the co-production of science and social order. Routledge, London

27. Jia L, Zhao Y, Liang X-J (2011) Fast evolving nanotechnology and relevant programs and entities in China. Nano Today 6(1):6-11

28. Kirsten G (2009) Cytotoxicity and oxidative DNA damage by nanoparticles in human intestinal Caco-2 cells. Nanotoxicology 3(4):355-364

29. Kulinowski KM (2007) The International Council on Nanotechnology: a new model of engagement, in Nansocale, pp 393-412

30. Li SH (2010) Small world, big results. Chinese Social Science News 11:1-2

31. McKibben B (2003) Enough: Staying human in an engineered age. Henry Holt, New York

32. Michelson, E. S. (2008). Globalization at the nano frontier: The future of nanotechnology policy in the United States, China, and India. Technology in Society 30.3-4, 405-10, p 406

33. Mnyusiwalla A, Daar AS, Singer P (2003) Mind the gap: science and ethics in nanotechnology. Nanotechnology 14 : R9-R13

34. National Science and Technology Development Plan 20092012, National Science Council, Executive Yuan, Taiwan, p 60

35. Oberdorster E (2004) Manufactured nanomaterials (Fullerenes, C60) induce oxidative stress in the brain of juvenile largemouth bass. Environ Health Perspect 112(10):1058-62

36. Oud M (2007) A European perspective. In: Hodge G, Bowman $\mathrm{D}$, Ludlow K (eds) New global frontiers in regulation. The age of nanotechnology. Edward Elgar, Cheltenham, pp 265-86

37. Pandza K, Wilkins A, Alfoldi E (2011) Collaborative diversity in a nanotechnology innovation system: evidence from the EU Framework Programme. Technovation 31(9):476-489

38. Purra M, Richmond N (2010) Mapping emerging nanotechnology policies and regulation: the case of Taiwan. Retrieved from http://www2.lse.ac.uk/internationalRelations/ centresandunits/regulatingnanotechnologies/nanopdfs/ Taiwan2010.pdf

39. Qi L (2008) Nanotechnology and nano-safety research must be synchronized. Science Times, 29th Jan, Section A04, Life Science

40. Response to the Royal Society and Royal Academy of Engineering Report: Nanoscience and nanotechnologies: Opportunities and uncertainties. (2005). Retrieved from http://www.bis.gov.uk/assets/bispartners/cst/docs/files/ nano-review/nanotech_final.pdf 
41. Schummer J (2007) Identifying ethical issues of nanotechnologies. In: ten Have HAMJ (ed) Nanotechnologies, ethics, and politics. UNESCO, Paris, pp 79-99

42. Shvedova AA, Kisin ER, Porter D, Schulte P, Kagan VE, Fadeel B, Castranova V (2009) Mechanisms of pulmonary toxicity and medical applications of carbon nanotubes: two faces of Janus? Pharmacol Ther 121(2):192-204

43. Song Y, Li X, Du X (2009) Exposure to nanoparticles is related to pleural effusion, pulmonary fibrosis and granuloma. European Respiratory Society. Retrieved from http:// www.ersj.org.uk/content/34/3/559.full

44. Spagnolo AG, Daloiso V (2009) Outlining ethical issues in nanotechnologies. Bioethics 23(7):394-402

45. Suttmeier RP, Cao C, Simon DF (2006) Knowledge innovation and the Chinese Academy of Sciences. Science 312:58-59

46. Tang L, Carley S, Porter AL (2011) Charting nano environmental, health, \& safety research trajectories: is China convergent with the United States? J Sci Pol Governance 1
(1):1-16, Retrieved from http://works.bepress.com/li_tang/ 9 on 20 January, 2012

47. Trouiller B (2009) Titanium dioxide nanoparticles induce DNA damage and genetic instability in vivo in mice. Cancer Res 69(22):8784-8789

48. Wang GY (2010) Nanotechnology safety and regulation. Daily News, 11 November 2010, 1-2

49. Widdows H (2007) Is global ethics moral neo-colonialism? An investigation of the issue in the context of bioethics. Bioethics 6(21):305-315

50. Wood S, Geldart A, Jones R (2008) Crystallizing the nanotechnology debate. Technology Analysis and Strategic Management 20(1):13-27

51. Ying HJ (2006) Managing the risks of nanotechnology development. Chinese Science Forum 5 (September 2006), 110-113

52. Zhao F, Zhao Y, Wang C (2008) Activities related to health, environmental and societal aspects of nanotechnology in China. J Clean Prod 16:1000-1002 